\title{
¿Impacts of Stratospheric Sulfate Geoengineering on Global Solar Photovoltaic and Concentrating Solar Power Resource ${ }^{\mathscr{O}}$
}

\author{
Christopher J. SMith,,${ }^{\mathrm{a}} \mathrm{b}$ Julia A. CroOK, ${ }^{\mathrm{a}}$ Rolf CroOK, ${ }^{\mathrm{b}}$ LAWrenCe S. JACKSON, ${ }^{\mathrm{a}}$ \\ SCOTT M. OSPREY, ${ }^{\mathrm{c}}$ AND PIERS M. FORSTER ${ }^{\mathrm{a}}$ \\ ${ }^{a}$ Institute for Climate and Atmospheric Science, School of Earth and Environment, University of Leeds, Leeds, \\ United Kingdom \\ ${ }^{\mathrm{b}}$ Energy Research Institute, School of Chemical and Process Engineering, University of Leeds, Leeds, \\ United Kingdom \\ ${ }^{\mathrm{c}}$ Department of Physics, University of Oxford, Oxford, United Kingdom
}

(Manuscript received 1 September 2016, in final form 18 January 2017)

\begin{abstract}
In recent years, the idea of geoengineering, artificially modifying the climate to reduce global temperatures, has received increasing attention because of the lack of progress in reducing global greenhouse gas emissions. Stratospheric sulfate injection (SSI) is a geoengineering method proposed to reduce planetary warming by reflecting a proportion of solar radiation back into space that would otherwise warm the surface and lower atmosphere. The authors analyze results from the Met Office Hadley Centre Global Environment Model, version 2, Carbon Cycle Stratosphere (HadGEM2-CCS) climate model with stratospheric emissions of $10 \mathrm{Tg} \mathrm{yr}^{-1}$ of $\mathrm{SO}_{2}$, designed to offset global temperature rise by around $1{ }^{\circ} \mathrm{C}$. A reduction in concentrating solar power output of $5.9 \%$ on average over land is shown under SSI relative to a baseline future climate change scenario (RCP4.5) caused by a decrease in direct radiation. Solar photovoltaic energy is generally less affected as it can use diffuse radiation, which increases under SSI, at the expense of direct radiation. The results from HadGEM2-CCS are compared with the Goddard Earth Observing System Chemistry-Climate Model (GEOSCCM) from the Geoengineering Model Intercomparison Project (GeoMIP), with $5 \mathrm{Tg} \mathrm{yr}^{-1}$ emission of $\mathrm{SO}_{2}$. In many regions, the differences predicted in solar energy output between the SSI and RCP4.5 simulations are robust, as the sign of the changes for both HadGEM2-CCS and GEOSCCM agree. Furthermore, the sign of the total and direct annual mean radiation changes evaluated by HadGEM2-CCS agrees with the sign of the multimodel mean changes of an ensemble of GeoMIP models over the majority of the world.
\end{abstract}

\section{Introduction}

Solar photovoltaics (PV) and concentrating solar power (CSP) have the potential to provide $11 \%$ and $16 \%$ of global electricity supply by 2050 , respectively (International Energy Agency 2014a,b). For offsetting energy production from fossil fuels, and for mitigation of

D Denotes content that is immediately available upon publication as open access.

Supplemental information related to this paper is available at the Journals Online website: http://dx.doi.org/10.1175/ JAMC-D-16-0298.s1.

Corresponding author e-mail: Christopher J. Smith, c.j.smith1@ leeds.ac.uk climate change, solar energy is a key technology. Previous work (Crook et al. 2011) assessed the responses of global CSP and PV energy output from the irradiance and temperature changes predicted under the future climate scenarios from the Special Report on Emission Scenarios (SRES) A1B pathway (Nakićenović et al. 2000), using two global climate models (GCMs). Large increases in CSP output are projected in Europe, the United States, Australia, and South America in 2080 compared to the recent past, with decreases in other regions. For PV, most regions except Europe will see a decrease in energy output toward the end of the twenty-first century. Changes predicted under the newer RCP8.5 emissions scenario (Moss et al. 2010), the highest radiative forcing pathway

This article is licensed under a Creative Commons Attribution 4.0 license (http://creativecommons. org/licenses/by/4.0/). 
from the set of Coupled Model Intercomparison Project phase 5 (CMIP5) pathways (Taylor et al. 2012), show a similar pattern for PV (Wild et al. 2015). While not extending their calculations to solar energy output, Huber et al. (2016) found that projected changes in total and direct radiation over the 2035-39 time frame compared to 1995-99 were positive in Europe, the Mediterranean, and Australia; neutral in the United States; and negative elsewhere under the A1B scenario. Contrastingly, simulations using regional climate models at higher spatial resolution for Europe show an expected decrease in solar PV output in most regions (Jerez et al. 2015), which is broadly in contradiction to studies using GCMs.

Alongside, or instead of, substituting fossil fuel energy generation with renewables such as solar, another more direct climate change mitigation idea is geoengineering. Geoengineering has been suggested as a way to reverse or lessen the impact of anthropogenic climate change (Boucher et al. 2013). The method of geoengineering considered in this paper is stratospheric sulfate injection (SSI), which is designed to reduce the incoming shortwave radiation by increasing Earth's planetary albedo, mimicking the effects of reflective volcanic sulfate aerosols (Budyko 1977; Crutzen 2006). The 1991 eruption of Mount Pinatubo ejected $20 \mathrm{Tg} \mathrm{SO}$ into the stratosphere (Bluth et al. 1992), causing a globally averaged cooling effect of about $0.5^{\circ} \mathrm{C}$ that was sustained for up to $3 \mathrm{yr}$ (Hansen et al. 1996; Lacis and Mishchenko 1995). Unlike well-mixed greenhouse gases, which are long-lived, stratospheric sulfate aerosols have a residence time of the order of about $2 \mathrm{yr}$ (Rasch et al. 2008), and therefore, SSI must continually replenish the aerosol burden. The resultant reflection of incoming solar radiation is expected to have adverse effects for solar power on Earth's surface (Robock et al. 2009). In the year following the Mount Pinatubo eruption, peak CSP capacity at the large solar electric generating station (SEGS) array in California was reduced by $20 \%$ (Murphy 2009). To the authors' knowledge, no previous studies have attempted to quantify the global changes in CSP and PV output following a large-scale SSI program, which is presented in this paper.

Other potential side effects of SSI include ozone depletion (Tilmes et al. 2008) and disruption to precipitation patterns (Jones et al. 2010; Niemeier et al. 2013). Increased emissions of $\mathrm{SO}_{2}$, both from industry and natural emissions from volcanoes, have been cited as a cause of drought in the Sahel (Haywood et al. 2013). Furthermore, SSI will not help to mitigate ocean acidification, and there may be other undesirable side effects that will only become known upon deployment of an SSI program (Robock et al. 2008). This paper does not seek to delve into these issues or to assess the ethics or practicalities of geoengineering.
In section 2, we introduce the climate models and solar power calculations. Section 3 analyzes the changes predicted for near-surface air temperature and direct and total surface downwelling radiation under SSI. Section 4 shows results for solar power output predicted under geoengineering with SSI compared to the base RCP4.5 simulation and the recent past, and section 5 provides a discussion and conclusions.

\section{Data and methods}

\section{a. $10 \mathrm{Tg} \mathrm{yr}^{-1} \mathrm{SO}_{2}$ injection on top of RCP4.5 in HadGEM2-CCS}

In this study, we use the high-top version of the Met Office Hadley Centre Global Environment Model, version 2, Carbon Cycle Stratosphere (HadGEM2-CCS) (Hardiman et al. 2012; Martin et al. 2011; Osprey et al. 2013) to simulate historical climate from 1860 to 2005 and future climate to 2099 based on the RCP4.5 emissions scenario (Moss et al. 2010). RCP4.5 is a moderate future climate change scenario, where atmospheric concentrations of greenhouse gases are prescribed and continue to increase throughout the twenty-first century. It is one of the four scenarios used by climate modeling centers in the CMIP5 project. Under RCP4.5, global annual mean temperatures are projected to be $2.4^{\circ} \mathrm{C}$ above the preindustrial baseline in 2100 (Rogelj et al. 2012), compared to the best estimate of $0.85^{\circ} \mathrm{C}$ in 2011 (Hartmann et al. 2013).

HadGEM2-CCS includes schemes for sea ice, ocean geochemistry, and the terrestrial carbon cycle, as well as interactive schemes for various aerosol species. The model atmosphere has 60 vertical levels extending to $84.5-\mathrm{km}$ altitude, which provides enhanced representation of stratospheric dynamics and radiation and a horizontal resolution of $1.25^{\circ}$ latitude by $1.875^{\circ}$ longitude. The ocean model has 40 vertical levels, a latitude resolution of $1^{\circ}$ between the poles and $30^{\circ} \mathrm{N}-\mathrm{S}$, increasing to $13^{\circ}$ at the equator, and a $1^{\circ}$ longitude resolution. The Coupled Large-Scale Aerosol Simulator for Studies In Climate (CLASSIC) aerosol scheme (Bellouin et al. 2011, 2007; Jones et al. 2001) includes gas phase oxidation of $\mathrm{SO}_{2}$ to $\mathrm{H}_{2} \mathrm{SO}_{4}$ in the stratosphere via reactions with the hydroxyl radical and was adapted to include stratospheretroposphere aerosol gravitational sedimentation. Equatorial emissions are dispersed poleward by the Brewer-Dobson circulation, producing a global although nonuniform radiative shield (Oman et al. 2005; Rasch et al. 2008).

Our SSI geoengineering model runs simulate the injection of $\mathrm{SO}_{2}$ from January 2020 onward at an altitude of $16 \mathrm{~km}$ to $25 \mathrm{~km}$ at one site over the equator and at a uniform rate of $10 \mathrm{Tg} \mathrm{yr}^{-1} \mathrm{SO}_{2}$ on top of RCP4.5. Injection over the equator in the lower stratosphere allows the $\mathrm{SO}_{2} / \mathrm{SO}_{4}$ to be carried to higher altitudes and 
poleward using the Brewer-Dobson circulation and maximizes sulfate coverage in time and space for a point injection (Jackson et al. 2015; Lenton and Vaughan 2009; Oman et al. 2005; Robock et al. 2008). The SSI scenario is based on the G4 experiment of the Geoengineering Model Intercomparison Project (GeoMIP) (Kravitz et al. 2011) but with a doubling of $\mathrm{SO}_{2}$ emissions from the original $5 \mathrm{Tg} \mathrm{SO}$ prescribed in G4. A previous $5 \mathrm{Tg} \mathrm{SO}_{2}$ experiment in HadGEM2-CCS resulted in global mean temperatures that were $0.4^{\circ} \mathrm{C}$ lower than a corresponding RCP4.5 simulation (Crook et al. 2015), which may not be a large enough difference to warrant an SSI intervention.

For the RCP4.5 and SSI simulations, the time frame of 2040-59 is used for analysis, as temperatures and radiation fluxes have had time to adjust to the geoengineering regime while conceivably being within the lifetime of solar collectors that are commissioned today. To compare future climate scenarios (SSI and RCP4.5) against the recent past, the historical simulation output for 1986-2005 is also analyzed. The historical simulation includes observed or best-estimate historical atmospheric and land-use forcing changes, both natural and anthropogenic, from the mid-nineteenth century to 2005 (Taylor et al. 2012). One historical ensemble member was produced along with three ensemble members of the SSI and RCP4.5 simulations. These ensemble members were made by continuing the historical run past 2005 under RCP4.5 forcing, perturbing the initial conditions from January 2006, and branching off the SSI runs from 2020 from the three RCP4.5 runs.

From the atmospheric concentrations of aerosols and trace gases, the solar radiation is calculated using the Edwards-Slingo radiation scheme (Edwards and Slingo 1996) included within HadGEM2-CCS. Outputs of total $(G)$ and diffuse $\left(G_{d}\right)$ shortwave downwelling radiation, both measured with respect to a horizontal surface, and near-surface air temperature $T_{a}$ (CMIP5 variable names rsds, rsdsdiff, and tas, respectively) are extracted for 2040-59 from each ensemble member in the SSI and RCP4.5 simulations and for 1986-2005 from the historical simulation, at a time frequency of $3 \mathrm{~h}$. Direct normal irradiance (i.e., in a plane normal to the solar beam) $G_{\mathrm{DNI}}$, which is not a variable normally output from climate model simulations, can be calculated as

$$
G_{\mathrm{DNI}}=\frac{G-G_{d}}{\cos \theta_{z}}
$$

where $\theta_{z}$ is the mean 3-h solar zenith angle, defined for daylight periods. Subroutines for calculating the solar position are included in the HadGEM2-CCS model code.
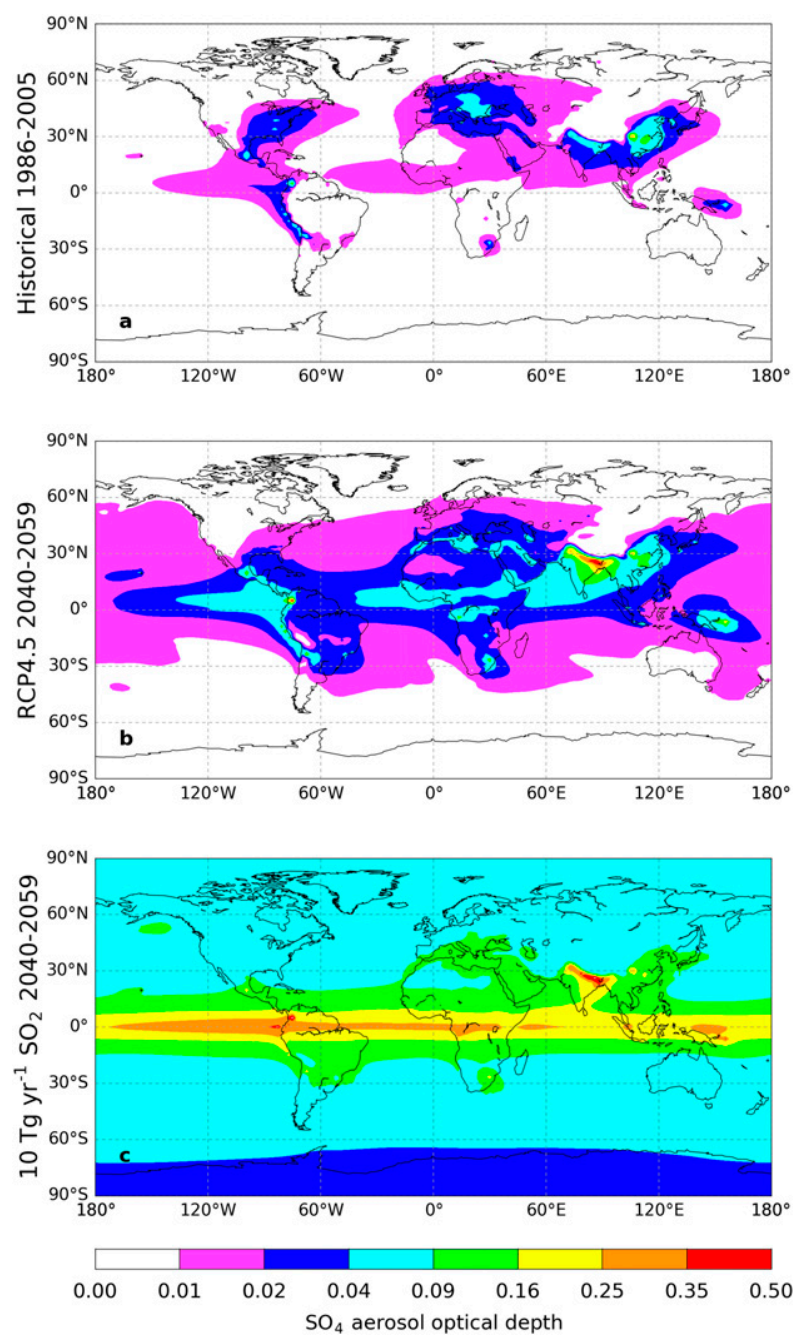

FIG. 1. $\mathrm{SO}_{4}$ aerosol optical depth at $550 \mathrm{~nm}$ in HadGEM2-CCS (a) historical (1986-2005), and (b) RCP4.5 and (c) SSI scenarios (both 2040-59).

Figure 1 shows the 20-yr mean global aerosol optical depths (AODs) of $\mathrm{SO}_{4}$ in each of the three simulations in HadGEM2-CCS. In the historical simulation (Fig. 1a), emissions are greatest from the industrialized regions in Europe, Asia, and North America. Baseline $\mathrm{SO}_{4}$ optical depths are higher in the RCP4.5 simulation (Fig. 1b), with clearly defined regions of AOD decrease in the United States and Europe caused by projected future clean-air policies and increase in much of the rest of the world caused by industrial expansion. In both of these scenarios, $\mathrm{SO}_{4}$ aerosol mostly resides in the troposphere. The 1991 Mount Pinatubo eruption is included in the historical simulation but is not included in the 20-yr average AOD. The latitudinal distribution of $\mathrm{SO}_{4}$ as a consequence of the Brewer-Dobson circulation is apparent in the SSI geoengineering simulation (Fig. 1c), where $\mathrm{SO}_{4}$ aerosol is resident mostly in the 
TABLE 1. Participating models in the GeoMIP G4 experiment. MIROC-ESM also participated alongside MIROC-ESM-CHEM; however, as the models are very similar, MIROC-ESM was not considered. The authors also performed runs under the G4 protocol with HadGEM2-CCS, and this model was also not included because of similarities with both HadGEM2-ES G4 and the HadGEM2-CCS 10 Tg yr ${ }^{-1}$ $\mathrm{SO}_{2}$ simulation. " $\mathrm{SO}_{2}$ injection" means that the model internally determines $\mathrm{SO}_{4}$ concentration (including particle size mode, if applicable) from $\mathrm{SO}_{2}$ concentrations, either from a point injection (i.e., including stratospheric dynamics) or as a stratospherically uniform layer. "Prescribed" aerosols are for those models that use a globally uniform concentration of $\mathrm{SO}_{4}$ aerosol. "Prescribed AOD" describes the case in which models do not contain a sulfate scheme and use a global distribution of $\mathrm{SO}_{4}$ aerosol optical depth. Full model names can be found at http://www.ametsoc.org/pubsacronymlist.

\begin{tabular}{|c|c|c|c|c|c|}
\hline Modeling center & Model name & $\begin{array}{l}\text { Near-surface } \\
\text { air temperature }\end{array}$ & $\begin{array}{l}\text { Total } \\
\text { radiation }\end{array}$ & $\begin{array}{l}\text { Direct } \\
\text { radiation }\end{array}$ & $\begin{array}{c}\text { Sulfate scheme } \\
\text { (Kravitz et al. 2013) }\end{array}$ \\
\hline $\begin{array}{l}\text { Beijing Normal } \\
\text { University }\end{array}$ & BNU-ESM & $\mathrm{X}$ & $\mathrm{X}$ & & $\mathrm{SO}_{4}$ prescribed \\
\hline $\begin{array}{l}\text { Canadian Centre for } \\
\text { Climate Modelling } \\
\text { and Analysis }\end{array}$ & CanESM2 & $\mathrm{X}$ & $\mathrm{X}$ & Monthly & $\mathrm{SO}_{4}$ prescribed \\
\hline NASA GISS/Rutgers & GISS-E2-R & $\mathrm{X}$ & $\mathrm{X}$ & & $\mathrm{SO}_{2}$ injection \\
\hline $\begin{array}{l}\text { NASA Goddard Space } \\
\text { Flight Center }\end{array}$ & GEOSCCM & & $\mathrm{X}$ & 3-hourly & $\mathrm{SO}_{2}$ injection \\
\hline Met Office Hadley Centre & HadGEM2-ES & $\mathrm{X}$ & $\mathrm{X}$ & & $\begin{array}{l}\mathrm{SO}_{2} \text { injection, } \\
\text { stratospherically } \\
\text { uniform }\end{array}$ \\
\hline $\begin{array}{l}\text { Japan Agency for } \\
\text { Marine-Earth Science } \\
\text { and Technology }\end{array}$ & MIROC-ESM-CHEM & $\mathrm{X}$ & $\mathrm{X}$ & & $\mathrm{SO}_{4}$ prescribed AOD \\
\hline Norwegian Climate Centre & NorESM1-M & $\mathrm{X}$ & $\mathrm{X}$ & Monthly & $\mathrm{SO}_{4}$ prescribed \\
\hline Total & & 6 & 7 & 3 & \\
\hline
\end{tabular}

stratosphere, and completely overwhelms the RCP4.5 baseline except for the Himalaya region, where the signal from RCP4.5 is strong.

\section{b. GeoMIP G4 experiments}

In addition to the $10 \mathrm{Tg} \mathrm{yr}^{-1} \mathrm{SO}_{2}$ simulation from HadGEM2-CCS, we analyze the outputs from seven GCMs that participated in the $5 \mathrm{Tg} \mathrm{yr}^{-1} \mathrm{SO}_{2}$ GeoMIP G4 experiment (Kravitz et al. 2011) (Table 1) to determine the regions in which changes predicted in the SSI simulation are robust. These simulations provide monthly means of near-surface air temperature and total radiation for both the G4 and RCP4.5 baseline climate change scenarios. Three models also provide monthly mean diffuse radiation, allowing the monthly differences in direct radiation between the $\mathrm{G} 4$ and RCP4.5 simulations to be determined. All models with the exception of the Goddard Earth Observing System Chemistry-Climate Model (GEOSCCM) are fully coupled atmosphere-ocean models. As GEOSCCM uses prescribed sea surface temperatures (SSTs) from its corresponding RCP4.5 run in its G4 simulation, the near-surface air temperature differences were not analyzed from this model. GEOSCCM is the only model in which 3-hourly diffuse and total radiation were available, so the model outputs (including near-surface air temperature) have been used to determine where differences predicted in solar energy output from the HadGEM2-CCS SSI simulation are robust (section 4). As
GEOSCCM uses prescribed SSTs, the cooling over land with SSI may not be as great as it would be in a coupled atmosphere-ocean model. However, we show in section $4 \mathrm{~b}$ that near-surface air temperature only plays a small part in determination of the change in total solar energy output.

\section{c. Calculation of solar power output}

Three solar power systems are considered: a fixedangle PV array, a two-axis tracking PV array, and a oneaxis tracking CSP parabolic trough. Crystalline silicon (c-Si) is currently the dominant PV cell material, composing over $90 \%$ of world PV production in 2013 (Phillips and Warmuth 2014). Therefore, the results reported are applicable to c-Si solar cells. Fixed-angle PV panels are the most common configuration for domestic-scale installations and utility plants. In this study, we consider the tilt angle to be equal to latitude, oriented toward the equator. Two-axis tracking PV modules use a control system to ensure that the module is angled to be normal to the solar beam. Two-axis trackers are more likely to be implemented in large solar PV arrays, especially those in regions with extensive direct sunlight. A tracking system increases the intensity of radiation on the panel by minimizing the incidence angle between the solar beam and the normal to the panel. Some of the electrical energy generated is required to operate the tracking system and the cost and maintenance burden is higher than for a fixed PV 
system. In areas with frequent cloud cover, the benefit of tracking systems may be minimal (Kelly and Gibson 2009). For CSP, direct sunlight is focused onto an absorber tube using concave mirrors, while diffuse sunlight is not utilized. The tube contains a heat transfer fluid, usually oil, which is heated by the concentrated sunlight. The fluid circulates and is used to raise steam to power turbine-driven electrical generators. Collectors track the sun to align the focused sunlight to the absorber tube. We consider a parabolic trough collector, such as the type seen in the SEGS array in the Mojave Desert in California (Kearney 1989), with a one-axis east-to-west tracking system.

\section{1) Pнотоvoltaics}

As PV uses both direct and diffuse radiation on a tilted plane, an appropriate assumption about the distribution of diffuse radiation is necessary. By assuming that diffuse radiation is distributed isotropically, the total radiation on a tilted plane $G_{T}$ can be calculated (neglecting surface reflectance) with a simple geometric relationship (Liu and Jordan 1961):

$$
G_{T}=G_{\mathrm{DNI}} \cos \theta_{\mathrm{PV}}+\frac{1+\cos \beta}{2} G_{d},
$$

where $\theta_{\mathrm{PV}}$ is the solar incidence angle between the solar beam and the normal to the collector surface, and $\beta$ is the inclination of the PV panel with respect to the horizontal. If $\beta$ is taken to be equal to latitude, $\theta_{\mathrm{PV}}$ is given by

$$
\cos \theta_{\mathrm{PV}}=\cos \theta_{z} \cos \beta+\sin \theta_{z} \sin \beta \cos \alpha,
$$

where $\alpha$ is the relative azimuth between the solar collector and the sun.

Although it is well known that the isotropic model is approximate (Gueymard 2009), the two-stream radiation codes used in GCMs do not provide sufficient information about the distribution of diffuse radiation to justify a more complex tilt assumption. The equal-to-latitude assumption is also not generally the optimal tilt angle for fixed-angle PV collectors (Smith et al. 2016). However, this is a more realistic refinement of previous analyses of long-term climate effects on PV that assume a horizontal alignment (Crook et al. 2011; Jerez et al. 2015; Wild et al. 2015).

For two-axis tracking PV, $\beta=\theta_{z}$ and $\alpha=0$ in Eqs. (2) and (3) so that $\cos \theta_{\mathrm{PV}}=1$ at all daylight moments.

The PV cell temperature $T_{c}$ is given by

$$
T_{c}=T_{a}+k G_{T},
$$

where, assuming that the PV module is open mounted and the free-stream wind speed does not heavily influence the convective heat transfer away from the module, $k=0.02933 \mathrm{~K} \mathrm{~W}^{-1} \mathrm{~m}^{-2}$ (Skoplaki et al. 2008). As changes in wind speed in climate simulations are negligible for changes in solar energy output (Jerez et al. 2015), this variable is not considered further.

The efficiency of the PV cell is related to its cell temperature according to the relationship (Evans 1981)

$$
\eta_{\mathrm{PV}}=\eta_{\mathrm{ref}}\left[1-\beta\left(T_{c}-25\right)+\gamma \log _{10} G_{T}\right]
$$

for $T_{c}$ in degrees Celsius. Typical temperature and radiation coefficients for c-Si are $\beta=0.45 \% \mathrm{~K}^{-1}$ and $\gamma=0.1$. Here, $\eta_{\text {ref }}$ is taken to be $15 \%$, which gives a cell efficiency of $19.5 \%$ at standard testing conditions of $1000 \mathrm{Wm}^{-2}$ irradiance and $25^{\circ} \mathrm{C}$ cell temperature. In our analysis, we consider only relative changes (although absolute changes are estimated in the online supplemental material), and therefore the calculations are independent of $\eta_{\text {ref }}$.

The output power is the product of the efficiency and radiation such that

$$
P_{\mathrm{PV}}=\eta_{\mathrm{PV}} G_{T} .
$$

\section{2) Concentrating SOlar POWER}

The efficiency of a one-axis east-to-west parabolic trough CSP collector is given by (Kalogirou 2004)

$$
\eta_{\mathrm{CSP}}=k_{0}-\frac{k_{1}\left(T_{i}-T_{a}\right)}{G_{\mathrm{DNI}} \cos \theta_{\mathrm{CSP}}},
$$

where $\theta_{\mathrm{CSP}}$ is the incidence angle between the solar beam and the normal to the collector mirror. For a oneaxis east-to-west tracking CSP collector, the solar incidence angle is (Kalogirou 2004)

$$
\cos \theta_{\mathrm{CSP}}=\cos l \cos h+\cos \delta \sin ^{2} h,
$$

where $l$ represents latitude, $h$ is solar hour angle $\left(-180^{\circ}\right.$ at local solar midnight and incrementing by $15^{\circ} \mathrm{h}^{-1}$ ), and $\delta$ is solar declination. The CSP mirrors are aligned in the north-to-south axis and track the sun as it traverses the sky from east to west. The tracking mechanism ensures the collector is normal to the sun in the east-to-west direction, whereas the incidence angle in the north-to-south direction is dependent on the latitude and time of year.

Experiments at Sandia National Laboratories using the industrial solar technology parabolic trough collector found the efficiency intercept $k_{0}=0.762$, and coefficient $k_{1}=0.2125 \mathrm{~W} \mathrm{~m}^{-2} \mathrm{~K}^{-1}$ in Eq. (7) for an inlet temperature of $T_{i}=115^{\circ} \mathrm{C}$ (Dudley 1995).

Output power is given by

$$
P_{\mathrm{CSP}}=\eta_{\mathrm{CSP}} G_{\mathrm{DNI}} \cos \theta_{\mathrm{CSP}} .
$$

In both the PV and CSP cases, annual energy output is determined by taking the sum of solar power output for 

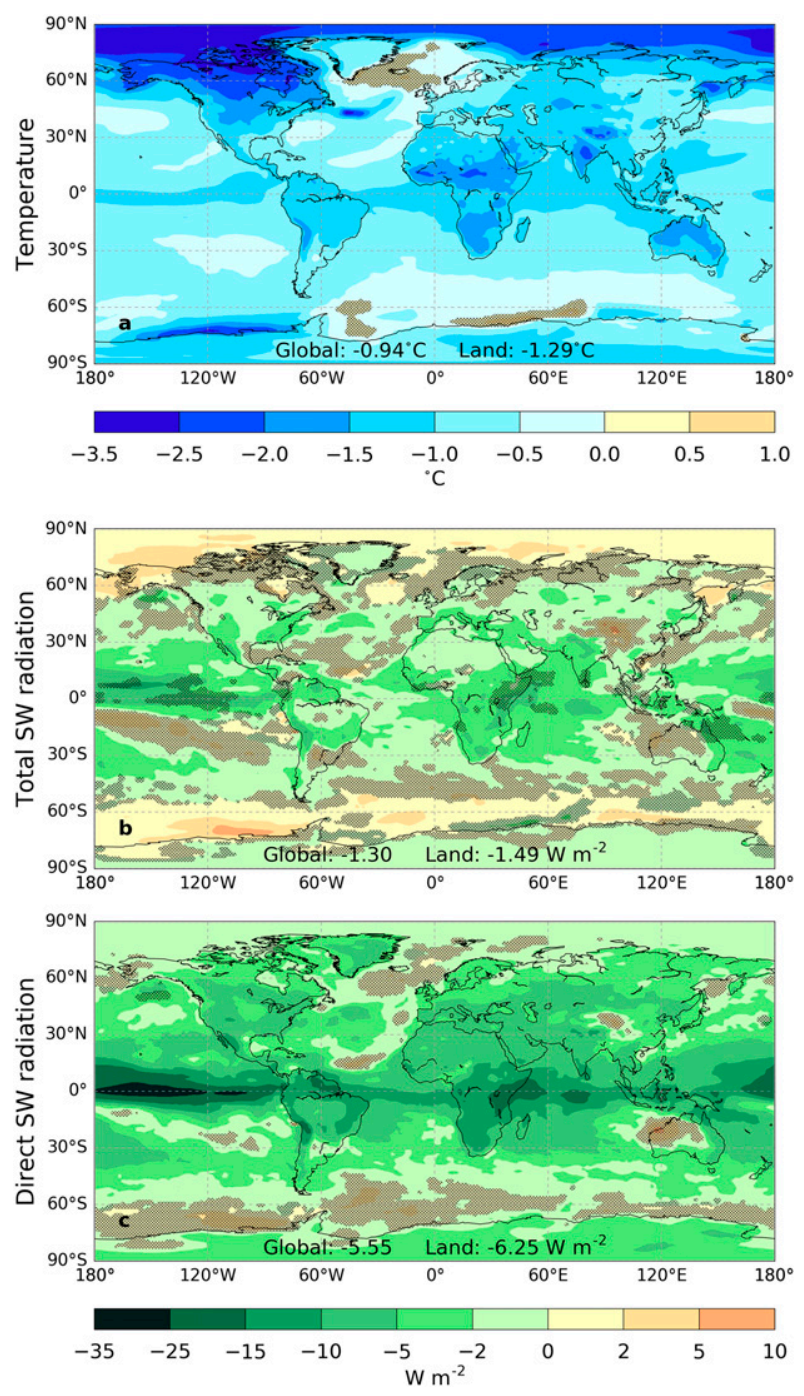

FIG. 2. Ensemble mean changes between the SSI simulation and RCP4.5 for (a) near-surface air temperature and (b) total and (c) direct downwelling shortwave radiation at the surface, respectively. Stippled regions are where the sign of the change in HadGEM2-CCS does not agree with the sign of the change in the mean of the GeoMIP models.

each 3-h period calculated over each year, and taking the mean of the $20 \mathrm{yr}$.

Equations (2)-(9) are repeated using 3-hourly climate model data from the GEOSCCM model from the RCP4.5 and G4 experiments.

\section{Differences in geoengineering and RCP4.5 climatologies}

Figure 2 shows the ensemble mean differences between our SSI and RCP4.5 simulations for temperature, total radiation, and direct radiation. Regions where the sign of the differences does not agree with the sign of the multimodel mean differences from the GeoMIP G4 models have been hatched.

SSI results in a global mean temperature of $0.94^{\circ} \mathrm{C}$ less than RCP4.5 with greater cooling over land $\left(1.29^{\circ} \mathrm{C}\right)$, which is robust everywhere except in the North Atlantic Ocean and the Southern Ocean (Fig. 2a). As shown in Fig. 3, these areas are where the GeoMIP models do not themselves agree on the sign of the difference between G4 and RCP4.5. The mean global temperature difference of $-0.54^{\circ} \mathrm{C}$ from the GeoMIP models is smaller in magnitude than that of HadGEM2-CCS, which would be expected because of the lower burden of $\mathrm{SO}_{4}$ present in the $\mathrm{G} 4$ experiments. It is interesting to note the very strong Arctic cooling shown by the HadGEM2-Earth System (ES) model (Fig. 3c) under the G4 regime that is not replicated in our SSI experiment with the related HadGEM2-CCS model, owing to the stratospherically uniform $\mathrm{SO}_{2}$ layer used in HadGEM2-ES. This leads to a greater $\mathrm{SO}_{4} \mathrm{AOD}$ in HadGEM2-ES over the polar regions and, hence, greater reflection of incident sunlight.

Global mean downwelling surface solar radiation is $1.30 \mathrm{~W} \mathrm{~m}^{-2}$ lower in the SSI simulation compared to RCP4.5. Over most land areas, the radiation differences are negative, but the global spatial pattern is more diverse than for temperature differences, with large areas showing an increase in total radiation under SSI compared to RCP4.5 (Fig. 2b). These differences are not seen in all G4 models (Fig. 4), and the predicted overall difference in total radiation is less robust. It can be inferred that low cloud fraction or thickness is lower in the SSI simulation than in the RCP4.5 simulation in the regions where total radiation is projected to increase.

For direct solar downwelling radiation at the surface, the differences between the SSI and RCP4.5 simulations are larger than for total radiation, especially across the equatorial band where $\mathrm{SO}_{2}$ is injected (Fig. 2c). These differences are globally more robust than for total radiation. Additionally, there are fewer regions where the (SSI - RCP4.5) difference is positive. Annual mean direct surface downwelling radiation is reduced by over $25 \mathrm{~W} \mathrm{~m}^{-2}$ in parts of the tropical Pacific Ocean, with a global average reduction of $5.55 \mathrm{~W} \mathrm{~m}^{-2}$. The largest surface shortwave differences occur in the tropics for SSI because, although the sulfate aerosol is spread across the globe by the Brewer-Dobson circulation, $\mathrm{SO}_{4}$ aerosol optical depth is greater near the equator where it is injected (Fig. 1c). The strong reduction in direct radiation across the equatorial band is not seen in the three GeoMIP models that provide diffuse radiation (Fig. 5). Two of the models (CanESM and NorESM1-M) use prescribed aerosol mass concentrations, whereas GEOSCCM uses $\mathrm{SO}_{2}$ injection (Kravitz et al. 2013). The lack of a large reduction in direct radiation across the 

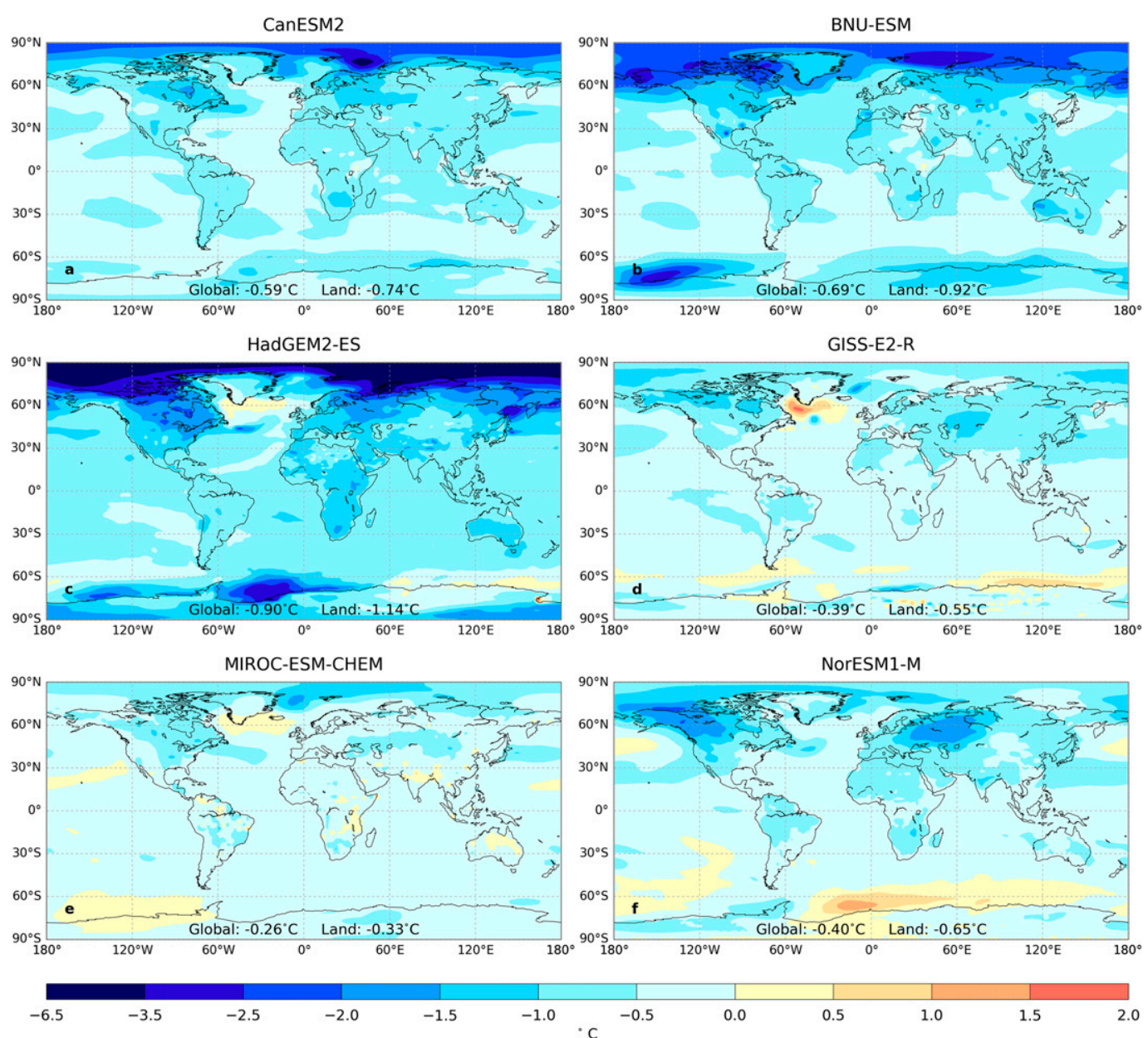

FIG. 3. Differences in near-surface air temperature between the GeoMIP G4 and RCP4.5 experiments for the six models for which data are available over the 2040-59 time frame.

equator in GEOSCCM suggests that the Brewer-Dobson circulation is better represented in this model than in HadGEM2-CCS.

In Fig. 6, the differences between the SSI and RCP4.5 simulations compared to the historical simulation are shown. Figures $6 \mathrm{a}$ and $6 \mathrm{~b}$ show that SSI is able to offset much of the additional warming present in RCP4.5. The spatial pattern of warming is similar in both simulations and does not appear to be related to the global distribution of $\mathrm{SO}_{4}$ as shown in Fig. 1. The spatial pattern of total solar downwelling radiation change in RCP4.5 is more heterogeneous than for temperature. However, this spatial pattern is not drastically affected by SSI (Figs. 6c,d). By contrast, the large decrease in direct radiation in most regions, but especially across the equatorial band, is apparent in the SSI simulation (Fig. 6e) when compared to RCP4.5 (Fig. 6f). Comparisons with the G4 models have only been analyzed for temperature and total solar downwelling radiation as historical diffuse radiation is not available in any of the G4 models. It is shown that the temperature and total radiation changes agree in sign with the multimodel mean changes from the G4 models in most areas.

\section{Geoengineering effects on solar energy}

\section{a. Differences between geoengineering and RCP4.5 simulations}

Figure 7 shows the differences in energy output between the SSI and RCP4.5 simulation ensemble means in HadGEM2-CCS, and G4 and RCP4.5 simulations in GEOSCCM, for each considered technology.

The differences for fixed-angle PV between SSI and RCP4.5 are generally small, at $-1.0 \%$ over land in HadGEM2-CCS (Fig. 7a) and $-1.7 \%$ in GEOSCCM (Fig. 7b). For tracking PV, the differences due to SSI compared to RCP4.5 are of a greater magnitude at $-2.8 \%$ over land in HadGEM2-CCS (Fig. 7c) 

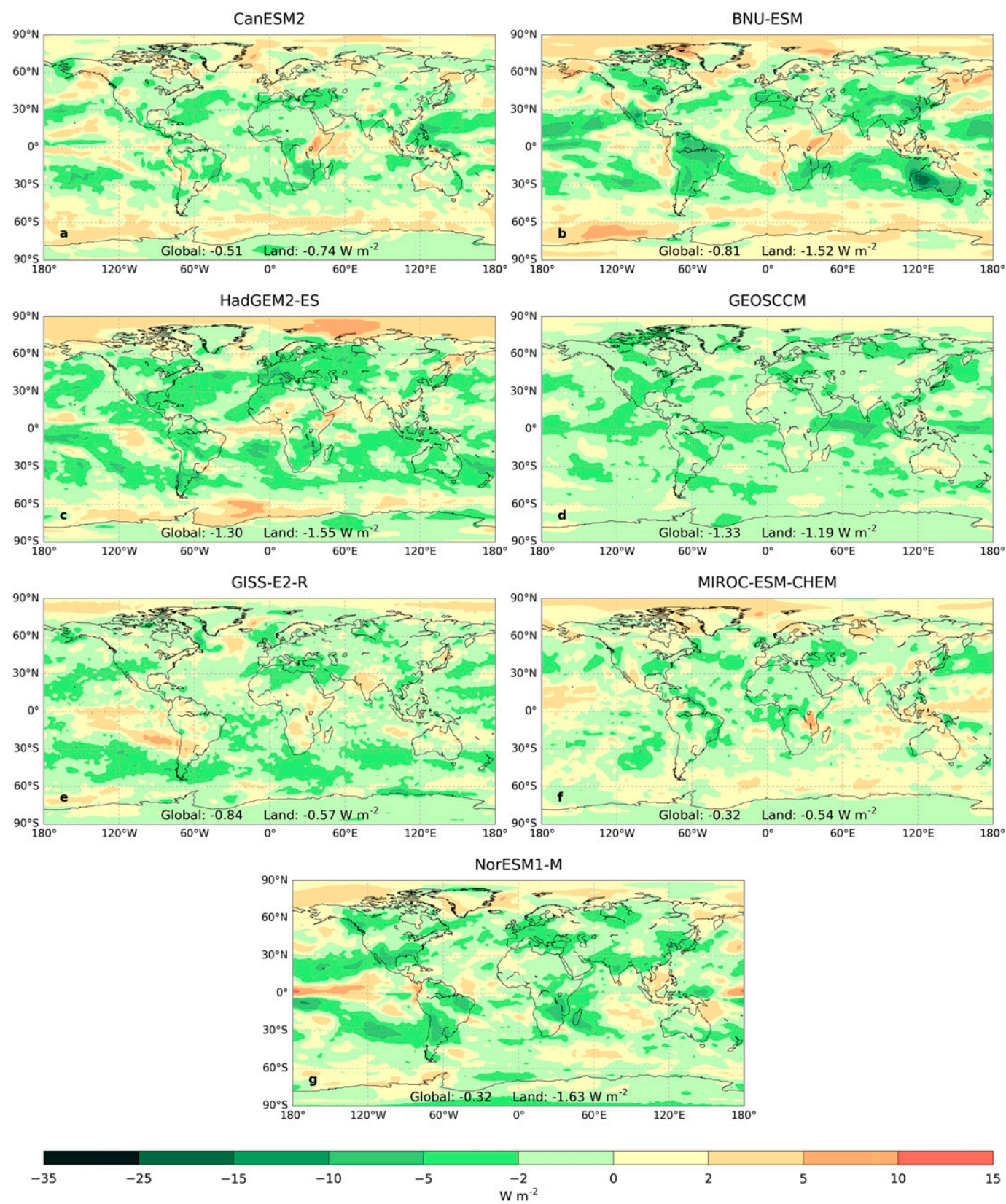

FIG. 4. As in Fig. 3, but for surface downwelling shortwave radiation for the seven models for which data are available.

and $-3.0 \%$ in GEOSCCM (Fig. $7 \mathrm{~d}$ ) and are negative in most regions. The reduction in direct radiation under SSI accounts for these differences, as tracking PV systems are more sensitive to changes in direct radiation.

Differences between SSI and RCP4.5 solar energy output are larger for CSP than for PV (Figs. 7e,f). Annual energy output is more than $10 \%$ lower in SSI than RCP4.5 for many regions in HadGEM2-CCS, particularly across the equatorial band. The land mean difference is $-5.9 \%$. Differences in output are lower in
GEOSCCM at $-4.7 \%$ in the land mean. The equatorial band is less pronounced but still present. The differences between fixed PV, two-axis tracking PV, and CSP can be explained by the fact that sulfate scattering increases diffuse radiation at the expense of direct radiation, whereas the decline in total radiation is smaller (Figs. 2b,c). Unlike CSP, PV can utilize both direct and diffuse radiation. Therefore, both PV and CSP output would decline in the case of a climate geoengineered using SSI (Oppenheimer et al. 2014; Robock et al. 2009), but the 

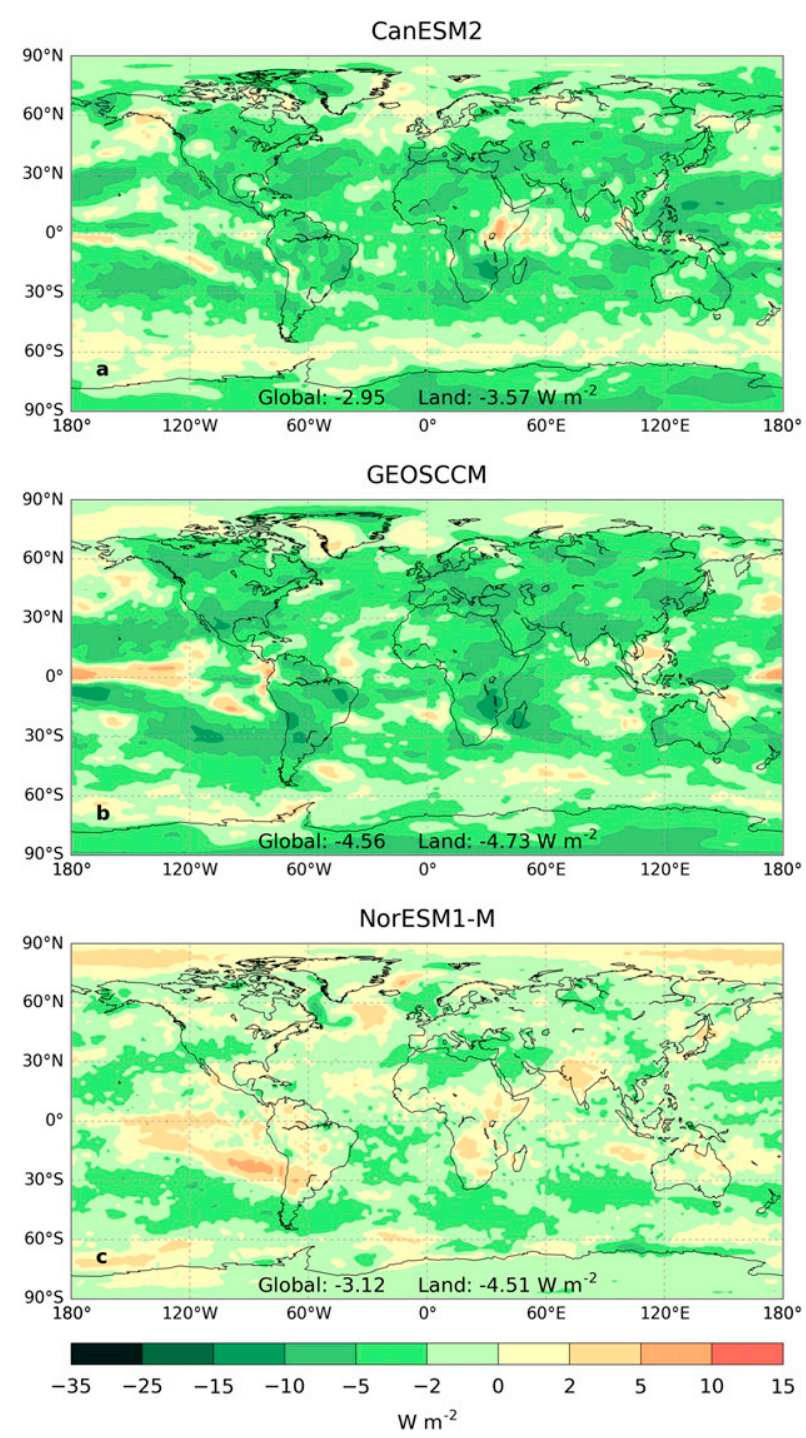

FIG. 5. As in Fig. 3, but for direct surface downwelling shortwave radiation for the three models for which data are available.

effect on CSP is greater. The differences in absolute solar energy output for HadGEM2-CCS are shown in online supplemental Fig. S1.

\section{b. Temperature and radiation contributions to solar energy differences}

To analyze the separate effects of radiation and temperature on each of the three technologies, we first set radiation to the SSI value and temperature to the RCP4.5 value, calculate the solar power output, and repeat this with radiation at RCP4.5 levels and temperature at SSI levels. Although radiation and temperature are in reality codependent and such a separation may not be physically consistent, the dependence of solar energy output on each effect provides insights into their relative importance. The HadGEM2-CCS climate data were used in both cases. It can be seen in Fig. 8 that the contributions from radiation are greater in magnitude than the contribution from temperature. For both fixed and two-axis tracking PV, a small positive change in energy output over land is seen as a result of lower global temperatures in the SSI simulation, which increases PV efficiency (Figs. 8b,d). For fixed PV, the decrease in temperature effect on power output offsets the decline in radiation effect by about $37 \%$ over land, whereas for tracking PV, this offset is $16 \%$. For CSP, the effect of temperature is very small (Fig. 8f). Therefore, although GEOSCCM uses fixed SSTs, it is still appropriate to use the outputs from this model, as nearsurface air temperature is of secondary importance for PV and negligible for CSP (Crook et al. 2011; Jerez et al. 2015).

\section{c. Differences between future and historical simulations}

The differences in both future simulations compared to the historical are shown in Fig. 9. SSI tends to accentuate the negative global trends present in RCP4.5 for PV (cf. Figs. 9b,d,f with Figs. 9a,c,e). Where regional changes are positive in RCP4.5 compared to the historical, they tend to be less positive or negative when comparing SSI to historical. For PV, there is an increase in energy output in Europe, the eastern United States, and eastern Asia in both simulations. This is likely due to reductions in total cloud cover in these regions (Wild et al. 2015) and, in addition, a large decrease in black carbon aerosol over eastern Asia that is present in RCP4.5. For CSP, SSI shows the same positive predicted changes in output in Europe, the United States, and eastern Asia compared to historical (Fig. 9e) that RCP4.5 shows (Fig. 9f), but the changes are less strong. Whereas the changes in most land areas for CSP are positive or neutral in RCP4.5, they are negative in most regions in SSI. The spatial pattern of changes predicted for RCP4.5 compared to climatology are broadly the same as those predicted in Crook et al. (2011) and Wild et al. (2015). Analyses differences with G4 models are not provided because of lack of available data for historical diffuse radiation from the GeoMIP models.

\section{d. Regional analysis}

Following Crook et al. (2011) and Wild et al. (2015), we analyze changes in solar energy output in nine regions that are currently important for solar energy generation (Table 2). For all regions and all technologies, with one exception (fixed PV in northwest China), the change under SSI (2040-59) compared to historical (1986-2005) is more negative than for RCP4.5 (in 

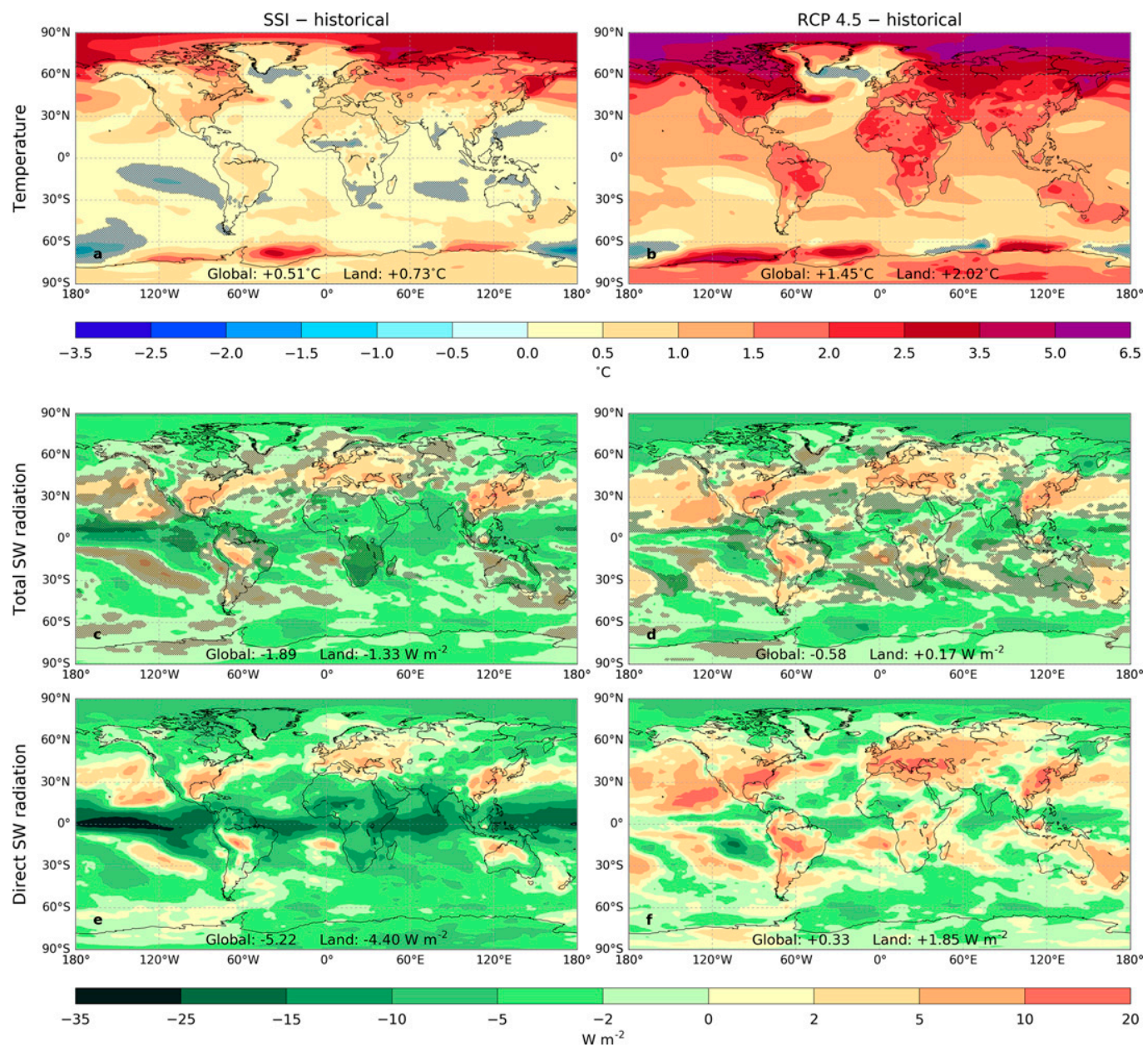

FIG. 6. Ensemble mean changes (left) between SSI and historical simulations and (right) between RCP4.5 and historical simulations for HadGEM2-CCS for (a),(b) near-surface air temperature; (c),(d) total downwelling shortwave radiation at surface; and (e),(f) direct shortwave radiation at surface. In (a)-(d), regions in which the sign of the change does not agree with the sign of the change from an ensemble of GeoMIP models have gray stippling. The stippling is not present for direct radiation as the historical GeoMIP data are not available.

HadGEM2-CCS). Furthermore, the changes predicted under SSI compared to historical are negative in all regions for all technologies except in Germany. Germany shows a strongly positive underlying change in solar energy output in RCP4.5 compared to historical, which is why SSI does not completely offset this. However, Germany is a relatively low insolation region. In the other eight focus regions, which can be classed as "high" insolation, SSI results in lower solar energy yield than historical.

\section{Discussion and conclusions}

It is shown that geoengineering using stratospheric sulfate injection at a rate of $10 \mathrm{Tg} \mathrm{yr}^{-1} \mathrm{SO}_{2}$ into the stratosphere is likely to result in negative changes in concentrating solar power output in most regions of the world. The global land mean decrease in annual energy output is $5.9 \%$ compared to the RCP 4.5 baseline climate change scenario for $2040-59$ and $4.5 \%$ compared to the historical simulation (1986-2005). By comparing the results to the projected energy output from the GEOSCCM model with an injection of $5 \mathrm{Tg} \mathrm{yr}^{-1}$ and the pattern of direct radiation change in the GEOSCCM, NorESM1-M, and CanESM2 models, the results predicted are likely to be robust. We also show that the changes in solar radiation distribution as a consequence of geoengineering are more important than changes in near-surface air temperature for all solar energy technologies, particularly CSP. There is no significant geographical shift in the current most favorable regions for solar energy production should SSI be implemented, but the output in these regions is negatively impacted (Table 2). 

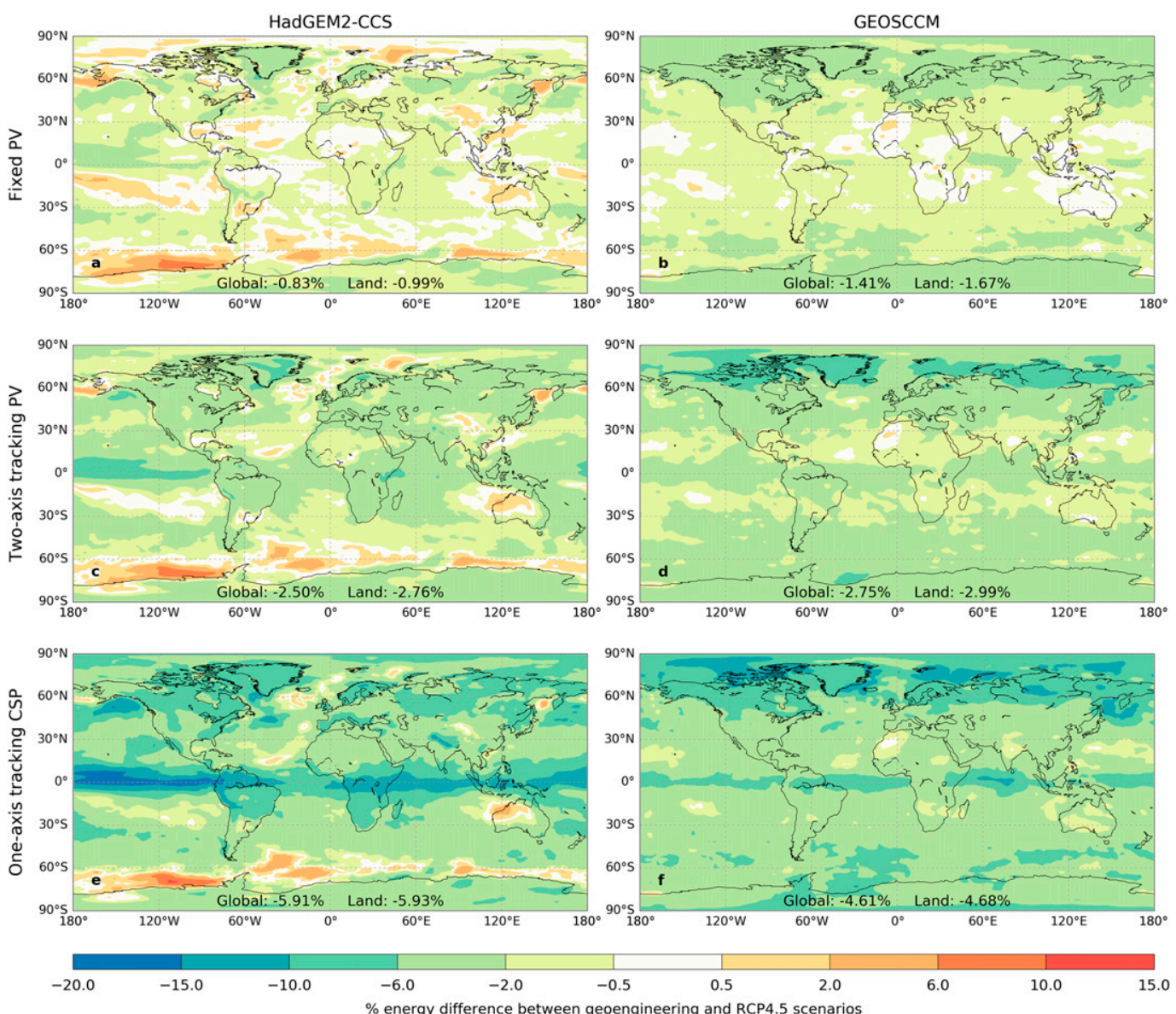

FIG. 7. Percentage changes in solar power output (left) between SSI and RCP4.5 simulations in HadGEM2-CCS and (right) between G4 and RCP4.5 in GEOSCCM. Changes in yield are for (a),(b) fixed-angle PV; (c),(d) twoangle tracking PV; and (e),(f) one-angle tracking CSP.

For PV, the effect of direct radiation changes can also be seen by accounting for the differences between twoaxis tracking PV and fixed-angle PV. The land average difference in energy output is lower between SSI and RCP4.5 than for CSP, at $2.8 \%$. For fixed-angle PV, however, the differences between the scenarios are much smaller $(1.0 \%)$ and less robust.

Other SSI scenarios have been suggested with climate goals that are distinct from offsetting global temperature rise, for example, injecting $\mathrm{SO}_{2}$ over the Arctic to control the reduction of sea ice (Jackson et al. 2015). As the Brewer-Dobson circulation would not return a large proportion of sulfate aerosol from the poles to lower latitudes, the differences in direct radiation in the Southern Hemisphere and tropical-midlatitude Northern Hemisphere between an SSI program designed to maintain sea ice and an unaltered climate may be much smaller. In addition, other solar radiation management methods have been proposed, such as cloud brightening, cirrus cloud thinning, surface albedo modification, and placing sunshades or space mirrors outside the atmosphere (Boucher et al. 2013). The other main geoengineering strategy, other than solar radiation management, is carbon dioxide removal from the atmosphere (Ciais et al. 2013). Again, we do not comment on the practicalities or ethics of these undertakings but discuss the possible implications for solar energy. Cloud brightening is intended to increase the albedo of clouds using sea-salt aerosol. This will reduce solar transmission through clouds but also reduce solar transmission in clear-sky areas where sea-salt aerosol is generated. On the other hand, cirrus cloud thinning, a method proposed to increase outgoing longwave radiation and, hence, cooling, will increase the incoming solar radiation slightly. A reduction in the solar energy reaching the atmosphere by deflection or refraction by space mirrors is likely to be more homogeneous in its negative impacts for solar energy than selective cloud modification. Increasing the surface albedo to reflect more solar radiation back to space is unlikely to have a direct negative impact on solar energy technologies and 

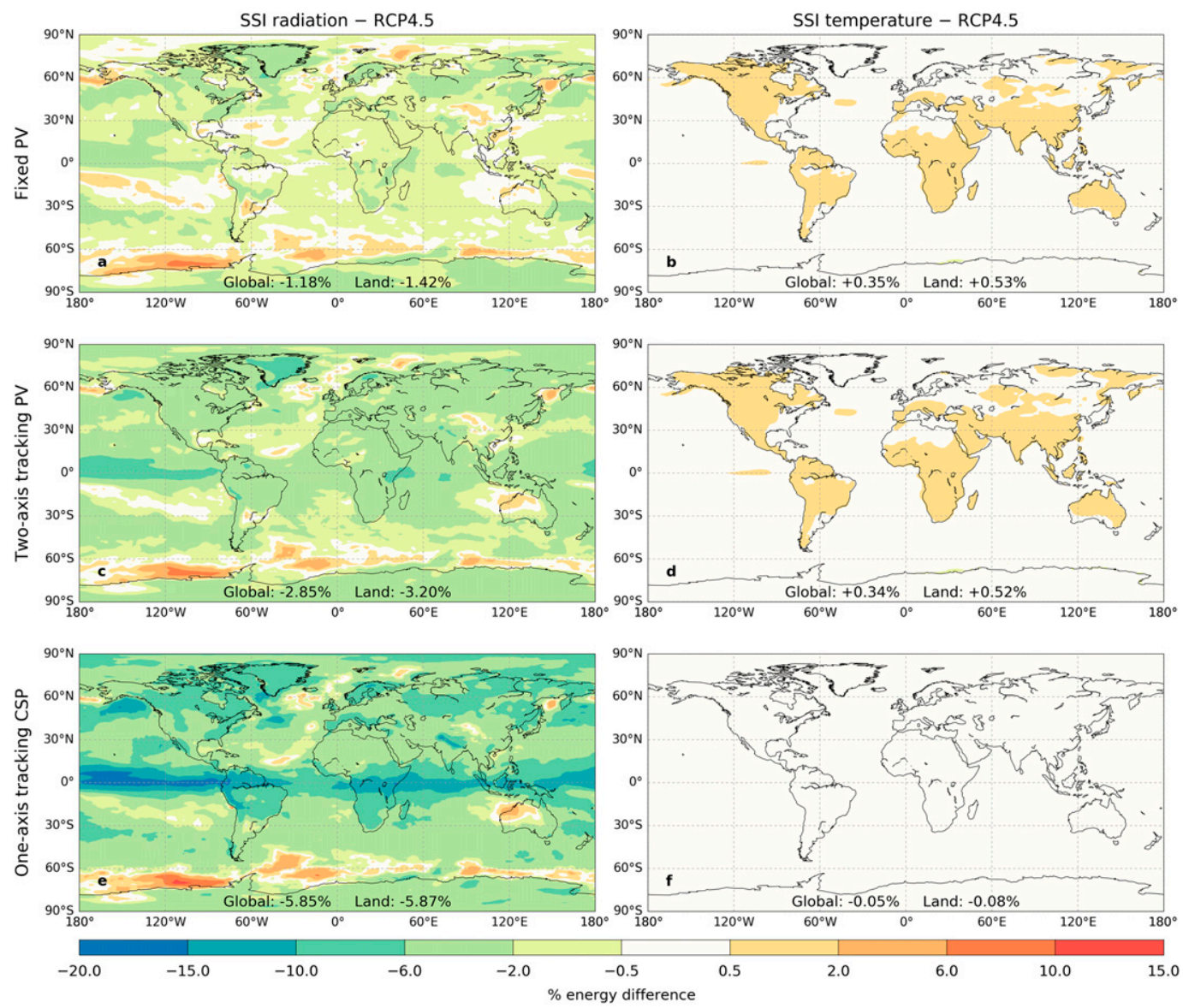

FIG. 8. Differences between SSI and RCP4.5 simulations due to (left) radiation and (right) temperature for (a),(b) fixed-angle PV; (c),(d) two-angle tracking PV; and (e),(f) one-angle tracking CSP. Absolute values are shown in online supplemental Fig. S2.

may be slightly positive because of additional solar radiation being reflected upward from the ground that collectors at nonhorizontal tilts can utilize. The direct effect of removing $\mathrm{CO}_{2}$ from the atmosphere would be a very small increase in shortwave radiation reaching Earth's surface. In all of these cases, changes in atmospheric heating rates, dynamics, and stability would occur, which will affect cloud feedbacks, and hence, the global distribution of radiation will differ under each geoengineering method.

As solar energy can help reduce future energy-related greenhouse gas emissions, it tackles one of the causes of climate change, whereas geoengineering only tackles the symptoms. We therefore do not foresee any advantage of selecting geoengineering over solar energy deployment as a climate change mitigation policy.

We have not assumed any technological progression in our calculations, and it is possible that some of the declines predicted would be offset partially or fully by improvements in efficiency. For PV, semiconductor material selection can be optimized for the incident spectrum, which will differ under a climate geoengineered with SSI. Finally, while local topographical and regional climate effects, along with human, economic, and environmental considerations, will always lead decisions on siting solar PV and CSP arrays, GCMs nonetheless provide an informative picture of the future changes to solar energy output that could be expected.

Acknowledgments. We thank all participants on the Integrated Assessment of Geoengineering Proposals (IAGP) project and acknowledge the financial support under Grant EP/I014721/1 from the Engineering and Physical Sciences Research Council (EPSRC) and Natural Environment Research Council (NERC). In addition, we thank the participating modeling centers of the GeoMIP project, in particular the NorESM, MIROC, and GISS groups, who provided their data following a personal request; the Earth System Grid Foundation (ESGF), British Atmospheric Data Centre (BADC), Beijing Normal University (BNU), and Canadian Centre for 

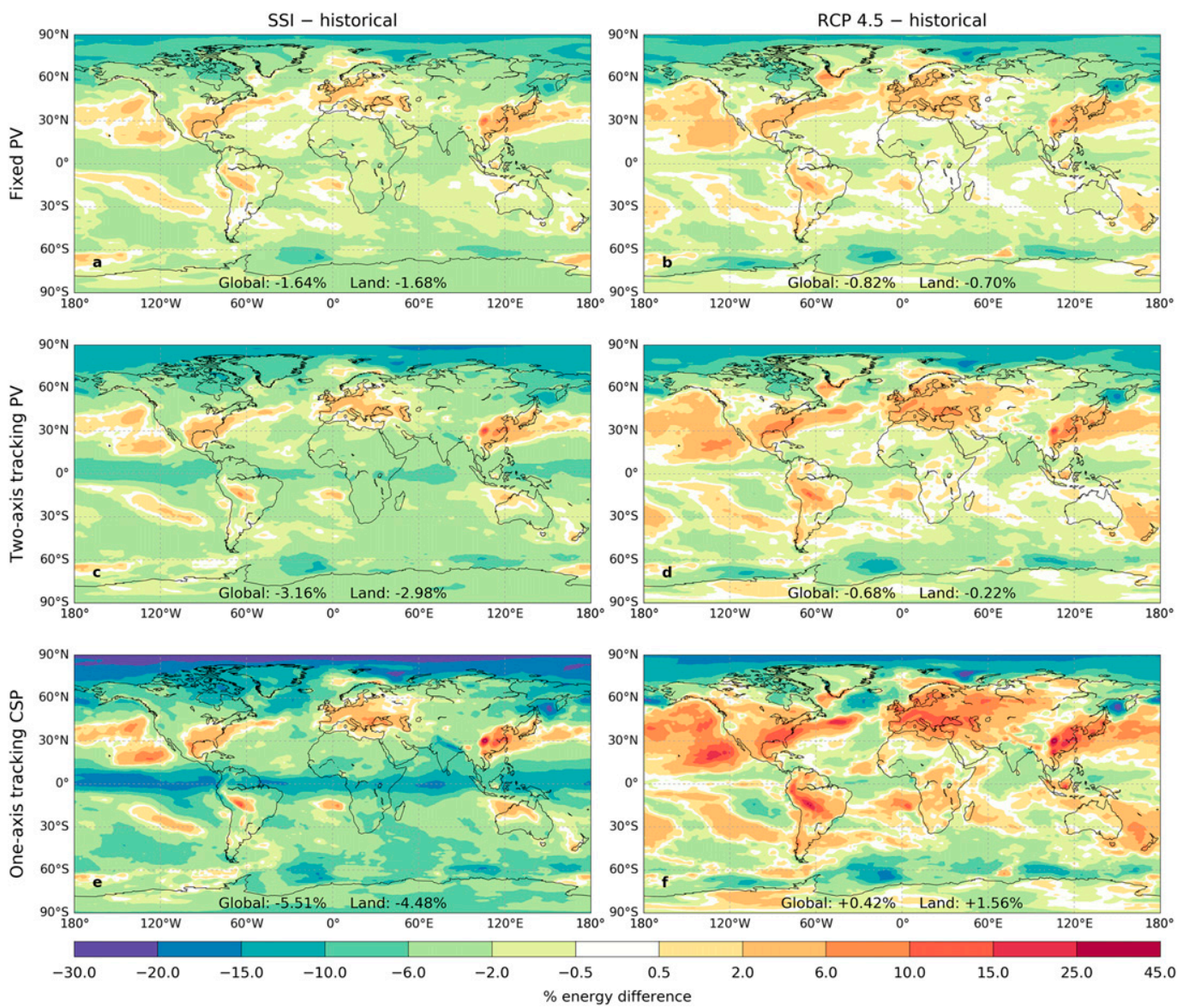

FIG. 9. Ensemble mean changes in solar power output in HadGEM2-CCS (left) between the SSI and historical simulations and (right) between RCP4.5 and historical simulations for (a),(b) fixed PV; (c),(d) two-axis tracking PV; (e),(f) one-axis tracking CSP. Absolute values are shown in online supplemental Fig. S3.

Climate Modelling and Analysis (CCCMA) for hosting and access to data; and the GeoMIP project coordinators. CJS was supported under Grant EP/G036608/1 from EPSRC through the University of Leeds Doctoral Training Centre in Low Carbon Technologies. PMF was supported by a Royal Society Wolfson Merit Award.
SMO was supported under the EPSRC funded Stratospheric Particle Injection for Climate Engineering (SPICE) project (Grant EP/I01473X/1). We acknowledge use of the MONSooN system, a collaborative facility supplied under the Joint Weather and Climate Research Programme, a strategic partnership between

TABLE 2. Regional changes in solar energy output (\%) from the SSI and RCP4.5 simulations (2040-59) in HadGEM2-CCS in comparison with the 1986-2005 historical simulation. These values correspond to Figs. 9a-f.

\begin{tabular}{|c|c|c|c|c|c|c|c|c|}
\hline \multirow[b]{2}{*}{ Region } & \multirow[b]{2}{*}{ Lon } & \multirow[b]{2}{*}{ Lat } & \multicolumn{2}{|c|}{ Fixed PV } & \multicolumn{2}{|c|}{ Tracking PV } & \multicolumn{2}{|c|}{ Tracking CSP } \\
\hline & & & SSI & RCP4.5 & SSI & RCP4.5 & SSI & $\mathrm{RCP} 4.5$ \\
\hline Algeria & $0^{\circ}-10^{\circ} \mathrm{E}$ & $30^{\circ}-37^{\circ} \mathrm{N}$ & -1.2 & -0.2 & -2.0 & 0.2 & -3.0 & 1.5 \\
\hline Australia & $140^{\circ}-150^{\circ} \mathrm{E}$ & $20^{\circ}-30^{\circ} \mathrm{S}$ & -1.3 & -0.8 & -1.3 & -0.4 & -1.4 & 0.9 \\
\hline California & $114^{\circ}-120^{\circ} \mathrm{W}$ & $32^{\circ}-40^{\circ} \mathrm{N}$ & -2.2 & -0.9 & -3.1 & 0.0 & -4.3 & 1.6 \\
\hline Northwest China & $90^{\circ}-100^{\circ} \mathrm{E}$ & $30^{\circ}-40^{\circ} \mathrm{N}$ & -1.5 & -2.3 & -2.6 & -2.5 & -4.1 & -2.1 \\
\hline Germany & $5^{\circ}-15^{\circ} \mathrm{E}$ & $47^{\circ}-52^{\circ} \mathrm{N}$ & 1.6 & 3.2 & 2.0 & 5.5 & 3.0 & 10.1 \\
\hline India (Gujarat) & $70^{\circ}-80^{\circ} \mathrm{E}$ & $20^{\circ}-30^{\circ} \mathrm{N}$ & -3.2 & -1.8 & -5.0 & -2.4 & -8.3 & -2.7 \\
\hline Saudi Arabia & $40^{\circ}-50^{\circ} \mathrm{E}$ & $20^{\circ}-30^{\circ} \mathrm{N}$ & -1.9 & -1.2 & -3.2 & -1.1 & -4.7 & -0.1 \\
\hline South Africa & $15^{\circ}-25^{\circ} \mathrm{E}$ & $20^{\circ}-35^{\circ} \mathrm{S}$ & -2.3 & -0.7 & -4.0 & -0.4 & -6.0 & 0.8 \\
\hline Spain & $0^{\circ}-8^{\circ} \mathrm{W}$ & $37^{\circ}-42^{\circ} \mathrm{N}$ & -0.5 & 1.9 & -1.2 & 2.8 & -1.8 & 5.2 \\
\hline
\end{tabular}


the Met Office and the Natural Environment Research Council.

We thank the editor Andrew Jones, Sonia Jerez, and one anonymous reviewer for their constructive comments, which improved the quality of this manuscript.

The authors declare no competing financial interests.

\section{REFERENCES}

Bellouin, N., O. Boucher, J. Haywood, C. Johnson, A. Jones, J. Rae, and S. Woodward, 2007: Improved representation of aerosols for HadGEM2. Hadley Centre Tech. Note 73, 42 pp. [Available online at http://www.metoffice.gov.uk/media/pdf/ 8/f/HCTN_73.pdf.]

— - J. Rae, A. Jones, C. Johnson, J. Haywood, and O. Boucher, 2011: Aerosol forcing in the Climate Model Intercomparison Project (CMIP5) simulations by HadGEM2-ES and the role of ammonium nitrate. J. Geophys. Res., 116, D20206, doi:10.1029/2011JD016074.

Bluth, G. J. S., S. D. Doiron, C. C. Schnetzler, A. J. Krueger, and L. S. Walter, 1992: Global tracking of the $\mathrm{SO}_{2}$ clouds from the June, 1991 Mount Pinatubo eruptions. Geophys. Res. Lett., 19, 151-154, doi:10.1029/91GL02792.

Boucher, O., and Coauthors, 2013: Clouds and aerosols. Climate Change 2013: The Physical Science Basis. T. F. Stocker et al., Eds., Cambridge University Press, 571-634.

Budyko, M. I., 1977: Climatic Changes. Amer. Geophys. Union, $271 \mathrm{pp}$.

Ciais, P., and Coauthors, 2013: Carbon and other biogeochemical cycles. Climate Change 2013: The Physical Science Basis. T. F. Stocker et al., Eds., Cambridge University Press, 465-570.

Crook, J. A., L. A. Jones, P. M. Forster, and R. Crook, 2011: Climate change impacts on future photovoltaic and concentrated solar power energy output. Energy Environ. Sci. 4, 3101-3109, doi:10.1039/c1ee01495a.

—_, L. S. Jackson, S. M. Osprey, and P. M. Forster, 2015: A comparison of temperature and precipitation responses to different Earth radiation management geoengineering schemes. J. Geophys. Res. Atmos., 120, 9352-9373, doi:10.1002/ 2015JD023269.

Crutzen, P., 2006: Albedo enhancement by stratospheric sulfur injections: A contribution to resolve a policy dilemma? Climatic Change, 77, 211-220, doi:10.1007/s10584-006-9101-y.

Dudley, V. E., 1995: Test results: Industrial solar technology parabolic trough solar collector. Sandia National Laboratories Rep. SAND94-1117, 140 pp. [Available online at http://www.osti.gov/ scitech/servlets/purl/211613.]

Edwards, J. M., and A. Slingo, 1996: Studies with a flexible new radiation code. I: Choosing a configuration for a large-scale model. Quart. J. Roy. Meteor. Soc., 122, 689-719, doi:10.1002/ qj. 49712253107.

Evans, D. L., 1981: Simplified method for predicting photovoltaic array output. Sol. Energy, 27, 555-560, doi:10.1016/ 0038-092X(81)90051-7.

Gueymard, C. A., 2009: Direct and indirect uncertainties in the prediction of tilted irradiance for solar engineering applications. Sol. Energy, 83, 432-444, doi:10.1016/j.solener.2008.11.004.

Hansen, J., R. Ruedy, M. Sato, and R. Reynolds, 1996: Global surface air temperature in 1995: Return to pre-Pinatubo level. Geophys. Res. Lett., 23, 1665-1668, doi:10.1029/96GL01040.

Hardiman, S. C., N. Butchart, T. J. Hinton, S. M. Osprey, and L. J. Gray, 2012: The effect of a well-resolved stratosphere on surface climate: Differences between CMIP5 simulations with high and low top versions of the Met Office climate model. J. Climate, 25, 7083-7099, doi:10.1175/JCLI-D-11-00579.1.

Hartmann, D. L., and Coauthors, 2013: Observations: Atmosphere and surface. Climate Change 2013: The Physical Science Basis. T. F. Stocker et al., Eds., Cambridge University Press, 159-254.

Haywood, J. M., A. Jones, N. Bellouin, and D. Stephenson, 2013: Asymmetric forcing from stratospheric aerosols impacts Sahelian rainfall. Nat. Climate Change, 3, 660-665, doi:10.1038/ nclimate1857.

Huber, I., L. Bugliaro, M. Ponater, H. Garny, C. Emde, and B. Mayer, 2016: Do climate models project changes in solar resources? Sol. Energy, 129, 65-84, doi:10.1016/j.solener.2015.12.016.

International Energy Agency, 2014a: Technology roadmap: Solar photovoltaic energy. International Energy Agency Rep., 43 pp. [Available online at https://www.iea.org/publications/ freepublications/publication/pv_roadmap.pdf.]

_ 2014b: Technology roadmap: Solar thermal electricity. International Energy Agency Rep., 46 pp. [Available online at https://www.iea.org/publications/freepublications/publication/ technologyroadmapsolarthermalelectricity_2014edition.pdf.]

Jackson, L. S., J. A. Crook, A. Jarvis, D. Leedal, A. Ridgwell, N. Vaughan, and P. M. Forster, 2015: Assessing the controllability of Arctic sea ice extent by sulfate aerosol geoengineering. Geophys. Res. Lett., 42, 1223-1231, doi:10.1002/ 2014GL062240.

Jerez, S., and Coauthors, 2015: The impact of climate change on photovoltaic power generation in Europe. Nat. Commun., 6, 10014, doi:10.1038/ncomms10014.

Jones, A., D. L. Roberts, M. J. Woodage, and C. E. Johnson, 2001: Indirect sulphate aerosol forcing in a climate model with an interactive sulphur cycle. J. Geophys. Res., 106, 20 293-20310, doi:10.1029/2000JD000089.

— J. Haywood, O. Boucher, B. Kravitz, and A. Robock, 2010: Geoengineering by stratospheric $\mathrm{SO}_{2}$ injection: Results from the Met Office HadGEM2 climate model and comparison with the Goddard Institute for Space Studies ModelE. Atmos. Chem. Phys., 10, 5999-6006, doi:10.5194/acp-10-5999-2010.

Kalogirou, S. A., 2004: Solar thermal collectors and applications. Prog. Energy Combust. Sci., 30, 231-295, doi:10.1016/j.pecs.2004.02.001.

Kearney, D., 1989: Solar electric generating stations (SEGS). IEEE Power Eng. Rev., 9, 4-8, doi:10.1109/39.87383.

Kelly, N. A., and T. L. Gibson, 2009: Improved photovoltaic energy output for cloudy conditions with a solar tracking system. Sol. Energy, 83, 2092-2102, doi:10.1016/j.solener.2009.08.009.

Kravitz, B., A. Robock, O. Boucher, H. Schmidt, K. E. Taylor, G. Stenchikov, and M. Schulz, 2011: The Geoengineering Model Intercomparison Project (GeoMIP). Atmos. Sci. Lett., 12, 162-167, doi:10.1002/asl.316.

,,- P. M. Forster, J. M. Haywood, M. G. Lawrence, and H. Schmidt, 2013: An overview of the Geoengineering Model Intercomparison Project (GeoMIP). J. Geophys. Res. Atmos., 118, 13 103-113 107, doi:10.1002/2013JD020569.

Lacis, A. A., and M. I. Mishchenko, 1995: Climate forcing, climate sensitivity, and climate response: A radiative model perspective on atmospheric aerosols. Aerosol Forcing of Climate, R. J. Charlson and J. Heintzenberg, Eds., John Wiley \& Sons, 11-42.

Lenton, T. M., and N. E. Vaughan, 2009: The radiative forcing potential of different climate geoengineering options. Atmos. Chem. Phys., 9, 5539-5561, doi:10.5194/acp-9-5539-2009.

Liu, B. Y. H., and R. C. Jordan, 1961: Daily insolation on surfaces tilted toward the equator. ASHRAE J., 3, 53-59. 
Martin, G. M., and Coauthors, 2011: The HadGEM2 family of Met Office Unified Model climate configurations. Geosci. Model Dev., 4, 723-757, doi:10.5194/gmd-4-723-2011.

Moss, R. H., and Coauthors, 2010: The next generation of scenarios for climate change research and assessment. Nature, 463, 747756, doi:10.1038/nature08823.

Murphy, D. M., 2009: Effect of stratospheric aerosols on direct sunlight and implications for concentrating solar power. Environ. Sci. Technol., 43, 2784-2786, doi:10.1021/es802206b.

Nakićenović, N., and Coauthors, 2000: Summary for policymakers. IPCC Special Report: Emissions Scenarios, Cambridge University Press, 1-20. [Available online at https://www.ipcc.ch/ pdf/special-reports/spm/sres-en.pdf.]

Niemeier, U., H. Schmidt, K. Alterskjær, and J. E. Kristjánsson, 2013: Solar irradiance reduction via climate engineering: Impact of different techniques on the energy balance and the hydrological cycle. J. Geophys. Res. Atmos., 118, 11905 11917, doi:10.1002/2013JD020445.

Oman, L., A. Robock, G. Stenchikov, G. A. Schmidt, and R. Ruedy, 2005: Climatic response to high-latitude volcanic eruptions. J. Geophys. Res., 110, D13103, doi:10.1029/ 2004JD005487.

Oppenheimer, M., and Coauthors, 2014: Emergent risks and key vulnerabilities. Climate Change 2014: Impacts, Adaptation, and Vulnerability. Part A: Global and Sectoral Aspects, C. B. Field et al., Eds., Cambridge University Press, 1039-1099.

Osprey, S. M., L. J. Gray, S. C. Hardiman, N. Butchart, and T. J. Hinton, 2013: Stratospheric variability in twentieth-century CMIP5 simulations of the Met Office climate model: High top versus low top. J. Climate, 26, 1595-1606, doi:10.1175/ JCLI-D-12-00147.1.

Phillips, S., and W. Warmuth, 2014: Photovoltaics report. Fraunhofer ISE. [Available online at https://www.ise.fraunhofer.de/content/ dam/ise/de/documents/publications/studies/PhotovoltaicsReport.pdf.]
Rasch, P. J., S. Tilmes, R. P. Turco, A. Robock, L. Oman, C.-C. Chen, G. L. Stenchikov, and R. R. Garcia, 2008: An overview of geoengineering of climate using stratospheric sulphate aerosols. Philos. Trans. Roy. Soc., 366A, 4007-4037, doi:10.1098/rsta.2008.0131.

Robock, A., L. Oman, and G. L. Stenchikov, 2008: Regional climate responses to geoengineering with tropical and Arctic $\mathrm{SO}_{2}$ injections. J. Geophys. Res., 113, D16101, doi:10.1029/ 2008JD010050.

—-, A. Marquardt, B. Kravitz, and G. Stenchikov, 2009: Benefits, risks, and costs of stratospheric geoengineering. Geophys. Res. Lett., 36, L19703, doi:10.1029/2009GL039209.

Rogelj, J., M. Meinshausen, and R. Knutti, 2012: Global warming under old and new scenarios using IPCC climate sensitivity range estimates. Nat. Climate Change, 2, 248-253, doi:10.1038/ nclimate1385.

Skoplaki, E., A. G. Boudouvis, and J. A. Palyvos, 2008: A simple correlation for the operating temperature of photovoltaic modules of arbitrary mounting. Sol. Energy Mater. Sol. Cells, 92, 1393-1402, doi:10.1016/j.solmat.2008.05.016.

Smith, C. J., P. M. Forster, and R. Crook, 2016: An all-sky radiative transfer method to predict optimal tilt and azimuth angle of a solar collector. Sol. Energy, 123, 88-101, doi:10.1016/ j.solener.2015.11.013.

Taylor, K. E., R. J. Stouffer, and G. A. Meehl, 2012: An overview of CMIP5 and the experiment design. Bull. Amer. Meteor. Soc., 93, 485-498, doi:10.1175/BAMS-D-11-00094.1.

Tilmes, S., R. Müller, and R. Salawitch, 2008: The sensitivity of polar ozone depletion to proposed geoengineering schemes. Science, 320, 1201-1204, doi:10.1126/science.1153966.

Wild, M., D. Folini, F. Henschel, N. Fischer, and B. Müller, 2015: Projections of long-term changes in solar radiation based on CMIP5 climate models and their influence on energy yields of photovoltaic systems. Sol. Energy, 116, 12-24, doi:10.1016/ j.solener.2015.03.039. 